\title{
TEOPИЯ
}

Богатырев В.В

\section{МЕЖДУНАРОДНО-ПРАВОВАЯ ВКЛЮЧЕННОСТЬ РОССИИ В СОВРЕМЕННЫЙ МИРОПОРЯДОК В АСПЕКТЕ СУБЪЕКТНОГО СОСТАВА РОССИЙСКОЙ ФЕДЕРАЦИИ}

Аннотация. В работе показывается международно-правовая включенность России в современный миропорядок в аспекте субъектного состава Российской Федерации. Включенность Российской Федераџии в универсальное международно-правовое пространство предопределено суверенным состоянием государственного существования страны. Постулат единой системы государственной власти в параметрах верховенства власти на всем пространственном протяжении Российской Федерации и независимости в международной сфере, как справедливо констатируют на этот счет ученые и практика международных судебно-арбитражных органов , устанавливают чёткий формат предметного восприятия понятия «суверенитет государства» («государственный суверенитет») Международно-правовое позиционирование Российской Федерации в качестве добросовестного участника системы современных международных правоотношений обозначено в формате государства со свойственной ему правоспособностью и дееспособностью. В своём статусе государства Российская Федераиия обладает таким неотъемлемым элементом, как международная правосубъектность: наличествует совокупность прав и обязанностей с параллельным существованием реальной юридической возможности выступить в зашиту с иелью обеспечения своих субъективных прав и законных интересов. В этом плане международная правосубъектность Российский Федерации по обязательствам своего сущностного юридического содержания ичеликом вписывается в общепризнанные на универсальном уровне стандарты доктринального восприятия понятия «международная правосубъектность». Теоретической и методологической основой исследования стали методы правового анализа, используемые в отечественной и зарубежной правовой науке: формально-юридический, системно-правовой, сравнительно-правовой, формально-логический и другие. Основными выводами проведенного исследования заключается в том, что выявлена международно-правовая значимость вклада Российской Федерации в дело поддержания современного правопорядка проявляет себя в параметрах обеспечения выполняемости всего корпуса международных обязательств на основе принципа добросовестности, укрепления Международного Суда, как главного судебного органа ООН, обеспечение иелостности универсальной системы международной безопасности, поддержание международной законности. Правопорядок по факту юридической включенности России в международную нормативную систему обретает реальные показатели поступательного продвижения мирового сообщества в направлении построения миропорядка на основе верховенства права в его сущностном восприятии. 
Ключевые слова: Российская Федерация, международная нормативная система, субъекты Российской Федерации, международная правосубъектность, независимость, суверенитет, государство, государственная власть, правовые стандарты, глобализация. Abstract: This work demonstrates the international legal inclusion of Russia in the modern world order in terms of the subject composition of the Russian Federation. The involvement of the Russian Federation into a universal international legal space destined to the sovereign State of the existence of the country. The postulate of a unified system of state power in the parameters of the rule of authority throughout the spatial extent of the Russian Federation and independence in the international arena, which is justly stated by the scholars and experts of international judicial and arbitral authorities, establishes a clear format of the subject perception of the concept of "state sovereignty". International legal positioning of the Russian Federation as a bona fide member of the system of modern international relations is indicated in the format of the state with the characteristic to it legal capacity. In its national status, the Russian Federation has such intrinsic element as the international legal personality: a combination of rights and responsibilities with the simultaneous existence of the actual legal opportunity to protect for ensuring its subjective rights and legal interests. In this regard, the international legal personality of the Russian Federation completely meets the general at the universal level standards of the doctrinal perception of the notion "international legal personality". The author determines that the international legal importance of the contribution of the Russian Federation into the support of the modern legal order manifests in execution of the entire frame of international obligations based on the good faith principle, as well as in strengthening of the International Court as the main judicial authority of the UN and provision of the integrity of the universal system of international security.

Keywords: Globalization, Legal standards, Government authority, Nation, Sovereignty, Independence, International legal personality, Constituents of the Russian Federation, International normative system, Russian Federation.

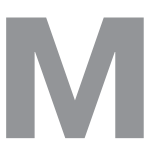

еждународно-правовое позиционирование Российской Федерации в системе современных международных правоотношений объективно обозначено предметным вкладом по линии поддержания режима верховенства права $[4$, с. $62-67 ; 5 ; 12$, с. $86 ; 19$, с. $5-17$; 26] по всему формату взаимодействия государств-членов мирового сообщества. Позитив международного права как он себя качественно проявляет в таких нормоустанавливающих документах современности, как Устав ООН (1945 г. ), Декларация тысячелетия 2000 г., Итоговый документ Всемирного саммита 2005 г., обретает реальные черты юридически действующего режима поведения государств по обстоятельствам предметной включенности Российской Федерации в современный миропорядок.

Современный миропорядок строится и осуществляет свою нормотворческую функцию в параметрах включенности суверенных государств. Согласительный характер строительства современного миропорядка предопределен заявительным согласием государств создать право, выполнять добросовестно предписания права и, по факту востребованности, осуществлять процедуру обеспечения права в рамках международных судебно-арбитражных органов. Вся совокупность нормоустанавливающих документов современности в формате Устава $\mathrm{OOH}$, Статута Международного суда $\mathrm{OOH}$, 
Декларации тысячелетия 2000 г., Итогового документа Всемирного саммита 2005 г. в силу своего юридического существа в качестве международных договорно-правовых актов создана и позиционно работает по факту жизнедеятельного существования суверенных государств. Именно суверенных, поскольку через проявление своего суверенного волеизъявления вовне государства изъявляют свое согласие выработать соответствующий международный юридический акт, а впоследствии содействовать его исполнению и с учетом востребованности осуществления добросовестного выполнения заложенных в нем международных обязательств обеспечить их юридическое функционирование. Создавая нормы международного правопорядка, изъявляя согласие их выполнять на основе принципа добросовестности и в конечном плане содействовать их обеспечению, государства выступают в режиме суверенного равенства (п. 1 ст. 2 Устава ООН). Юридическое равенство в параметрах миропорядка на основе верховенства права, а, с учетом присущего государствам суверенитета, суверенное равенство государств в формате императивного принципа суверенного равенства государств, являет собой базовый источник жизнедеятельного функционирования современного международного правопорядка. Российское государство как признанный суверен международной нормативной системы работает на позитив ее последовательного созидательного существования.

Российская Федерация в её качестве суверенного государственного образования, Великой державы, постоянного члена Совета Безопасности Организации Объединенных Наций проводит последовательный внешнеполитический курс на претворение в жизнь целей и принципов Устава ООН во всей их целостности и предметной завершенности. В порядке заявленной приверженности вер- ховенству права (Декларация тысячелетия 2000 г. , Итоговый документ Всемирного саммита 2005 г. ) Российская Федерация в параметрах её статусного положения в мире осуществляет целенаправленную деятельность по обеспечению добросовестного выполнения всеми государствами-членами мирового сообщества своих международных обязательств (ч. 2 ст. 2 Устава ООН). Позитив международного права, как он предметно обозначен по факту таких нормоустанавливающих документов современности, как Устав ООН, Декларация тысячелетия 2000 г., Итоговый документ Всемирного саммита 2005 г., по обязательствам активной внешнеполитической позиции Российской Федерации постановленным образом переходит в позитив практики поведения государств-участников современной системы международных правоотношений.

Включенность Российской Федерации в универсальное международно-правовое пространство предопределено суверенным состоянием государственного существования страны. Постулат единой системы государственной власти в параметрах верховенства власти на всем пространственном протяжении Российской Федерации и независимости в международной сфере, как справедливо констатируют на этот счет ученые $[21 ; 15$, . c. $125-141 ; 13$, с. $106-130 ; 21$, с. $65-66 ; 8$, с. $104-$ 129; 31, . Р. 3-19] и практика международных судебно-арбитражных органов [34, p. 45-46], устанавливают чёткий формат предметного восприятия понятия «суверенитет государства» («государственный суверенитет») Международно-правовое позиционирование Российской Федерации в качестве добросовестного участника системы современных международных правоотношений обозначено в формате государства со свойственной ему правоспособностью и дееспособностью. В своём статусе государства Российская Федерация обладает таким неотъемлемым 
элементом, как международная правосубъектность: наличествует совокупность прав и обязанностей с параллельным существованием реальной юридической возможности выступить в защиту с целью обеспечения своих субъективных прав и законных интересов. В этом плане международная правосубъектность Российский Федерации по обязательствам своего сущностного юридического содержания целиком вписывается в общепризнанные на универсальном уровне стандарты доктринального восприятия понятия «международная правосубъектность». В деле о возмещении ущерба, вынесенном Международным судом в 1949 г. понимание международной правосубъектности было обозначено в формате способности обладания международными правами и обязанностями и способности утверждения своих прав путём выдвижения международно-правовых требований [26, Р. 178-179].

Местом, где Российская Федерация может в соответствии с международным правом выступить с целью обеспечения своей юридической безопасности (совокупность субъективных прав и законных интересов) является Международный суд ООН. Процедурный аспект обращения в Международный суд в рамках современного международного права обозначен в формате присутствия согласия государства по линии достижения компромиссного соглашения (компромисса), односторонней декларации о признании обязательной юрисдикции суда (таковых на данный момент является шестьдесят пять деклараций) [28, Р. 115], соответствующего договорно-правового постановления в многопрофильном международном юридическом акте (договорная клаузула). Российская Федерация как государство, предметно заявившее о своей приверженности верховенству праву (Rule of Law) [4, c. $62-67,5,24 ; 29$, p. 81; 32, p. 223; 39 , р. $269 ; 36]$, вполне обоснованно рассма- тривает Международный суд как орган по обеспечению международного права вообще и своих собственных субъективных прав и законных интересов в частности. Именно в этом плане Российская Федерация в порядке выполнения предписаний Декларации тысячелетия 2000 г., Итогового документа Всемирного саммита 2005 г. - этих двух основополагающих документов современности - содействует в своем качестве как суверенное государство укреплению Международного суда.

Включенность Российской Федерации в международную нормативную систему установлена в параметрах её государственного суверенитета и оформлена в режиме принципа суверенного равенства государств (п. 1 ст. 2 Устава ООН). Постановочно, в предметном режиме принципа суверенных государств Российская Федерация через процедуру осуществления и реализации своего суверенитета как целостного территориального, независимого вовне на всём протяжении государства проводит всестороннее сотрудничество с государствами-членами мирового сообщества. Вступление Российской Федерации в международные договорно-правовые отношения с другими государствами осуществляется именно с позиций осуществления соответственно реализации своего суверенитета, а никак не через его ограничение. Проведение юридических действий по линии договорно-правового взаимодействия с государствами-членами мирового сообщества Россия, как государство, осуществляет посредством провозглашения своего собственного волеизъявления вступить в договорные отношения и, соответственно, заключить соответствующий договор. Положение международного права о том, что вступление государства в договорно-правовые отношения с другими государствами предпринимается не с позиций ограничения (самоограничения) 
суверенитета, а с позиций его предметного проявления подтверждено на основе последовательной практики международных судебно-арбитражных органов. Так, в решении Постоянной палаты международного правосудия по делу «Уимбледон» («Wimbledon») [33, Р. 28], которое было вынесено в 1923 г. , конкретно сказано: «Суд не усматривает в заключении какого-либо договора, по которому государство обязуется совершить определенное действие или воздержаться от совершения определённого действия, отказ от его суверенитета: право вступать в международное соглашение является атрибутом его государственного суверенитета».

Перевод концептуального позитива международного права в формат его практической реализации в общих параметрах включенности Российской Федерации как суверенного государства в процесс международного договорного взаимодействия осуществляется в чётких рамках юридического (а применительно к государствам-суверенного) равенства - per in parem non habet jurisdictionem. При обстоятельствах, когда принцип суверенного равенства государств признан в качестве нормоустанавливающего принципа современного миропорядка (п. 1 ст. 2 Устава ООН) государства в формате юридического равенства призваны уважать суверенитет друг друга и не допускать вмешательства во внутреннюю компетенцию друг друга. Общим правилом здесь является не просто взаимное уважение суверенитета и недопустимость какого-либо вмешательства, а режим добросовестного поведения контрагентов по международной нормативной системе. Государство в формате своего суверенитета призвано так строить свое поведение, при котором пользование субъективным правом было сопряжено с ненарушением обязательства по недопустимости нанесения ущерба субъективным правам другого государства-контрагента по современной международной нормативной системе. Эта грань между добросовестным пользованием своими субъективными правами со стороны одного государства (в порядке осуществления им своего суверенитета) по отношению к другому государству (с учетом уже его суверенитета) обозначается по обязательствам соблюдения параметров должного поведения всех государств-членов мирового сообщества. Таким параметром должного поведения государств по общему признанию науки $[2$, с. 114,$117 ; 3$, с. $85-86 ; 35$, S. $125,127,128$ 129; 30, Р. 171] и практики [27, Р. 269] современного права выступает принцип добросовестности bone fides. Установление принципа добросовестности в базисную структуру международно-правовой позиции Российской Федерации по линии всестороннего взаимодействия с другими государствами-членами мирового сообщества предопределило саму юридическую основу включенности России в международную договорную систему в соответствии с постановлениями Венской конвенции 1969 г. о праве международных договоров, Венской конвенции о правопреемстве государств в отношении международных договоров 1978 г., Венской конвенции о праве договоров между государствами и международными организациями или между международными организациями 1986 г.

Установочно, вхождение любого суверенного субъекта международного права в договорно-правовую или обычно-правовую систему международного взаимодействия осуществляется в порядке личностного участия в качестве государства. Вне зависимости от того, построено ли государство в режиме унитарного государства, либо на условиях федеративного или конфедеративного обустройства, государство вовне своего внутреннего правопорядка всегда выступает в формате единства системы 
государственной власти, государственного верховенства на всём пространственном протяжении страны, независимости по линии международного участия в современном миропорядке. В том, что касается предметно международной договорной системы, то здесь положение «каждое государство обладает правоспособностью заключать договор», (ст. 6 Венской конвенции о праве международных договоров 1969 г. ) несёт в себе характер предписывающего постановления. Именно государство в формате целостного суверенного образования «обладает правоспособностью заключать договора», поскольку именно оно (а не какая-либо его часть в режиме отдельного субъекта внутригосударственного правопорядка) выходят на международную арену как суверен. Государственный суверенитет принадлежит только исключительно государству как субъекту международного правопорядка. Выход субъекта внутригосударственного правопорядка в параметры международного правопорядка представляется с точки зрения юридической логики неприемлемым. Здесь в общем порядке действует режим согласия со стороны суверена-всего государства в целом. Это правило является нормоустанавливающим фактором нормального с точки зрения права функционирования международного и внутригосударственного правопорядка. Российское государство в порядке заявленной приверженности верховенству права предметно вписывается (по обстоятельствам своего юридически значимого правомерного поведения) в общеустанавливающие понятия соотношения участия субъекта международного правопорядка и субъекта внутригосударственного правопорядка в формате международного взаимодействия членов мирового сообщества. Вхождения Российского государства в договорно-правовые отношения с другим государством при обстоятельствах, когда затрагиваются интересы субъекта Российского государства, согласно общеюридической логики призвано быть осуществляемым в режиме взаимосогласования и представления вариантного решения собственного видения проблемы (общим правилом здесь может выступать представление соответствующих предложений по линии текстуального оформления содержательной части международного договора) в точные временные параметры права. Прохождение соответствующий юридически критической даты в формате точно установленных временных параметров без представления каких-либо юридических документов с вариантным решением собственного обеспечения своих субъективных прав с точки зрения современного международного права вполне обоснованно рассматривается как отказ (в данном случае речь идет не об одностороннем юридическом акте отказе, а об отказе в формате конвенционного акта отказа). Заявитель, а в конкретном плане - это субъект внутригосударственного правопорядка, призван в порядке обеспечения своих субъективных прав представить собственные позитивные предложения по направлению содержательной, юридической части международного договора. Непредставление со стороны субъекта внутригосударственного правопорядка собственных позитивных предложений в части составления взаимосогласованного текста международного договора субъекта международного правопорядка помимо того, что никак не препятствует завершению процедурных аспектов в плане заключения (субъектом международного правопорядка) международного договора, но, в принципе, лишает субъекта внутригосударственного правопорядка возможности по обеспечению своих предположительных интересов по линии закрепления в тексте подлежащего 
заключению международного договора собственных, сугубо субъективных, прав.

Представленное в современной науке [21, с. $65-66 ; 9$, с. $52-102 ; 14$, с. 124-140;20, с. $223-275 ; 13$, с. $111-118 ; 7$, с. 9-76;6, с. 79-89] и практике [22, Р. 116, 138-139] концептуальное мнение всецело подтверждает высказанную здесь юридическую картину взаимодействия субъекта международного правопорядка и входящего в его состав субъекта внутригосударственного правопорядка по линии заключения международного договора с учетом вовлеченности здесь полномочий (субъективных прав) субъекта внутригосударственного правопорядка. Стабильность международных договорно-правовых отношений предметно содействует стабильности международной нормативной системы в целом. В ситуации, когда непредставление в установленные временные параметры субъектом внутригосударственного правопорядка подлежащих быть представленных документов по линии предложений к предполагаемому к заключению (со стороны субъекта международного правопорядка, куда входит в качестве составной части государства субъект внутригосударственного правопорядка) международного договора справедливо рассматривается в международном праве как отказ, сам акт отказа не может быть квалифицирован в формате уже данного феномена. Юридический факт в режиме констатации отсутствия заявительных действий со стороны субъекта внутригосударственного правопорядка (при обстоятельствах конкретной востребованности представления в должные временные параметры собственных предложений по линии обеспечения субъективных прав в части заключаемого международного договора) не может презюмироваться как принцип. В качестве общего принципа права (по смыслу ст. 38 Статута Международного суда) принцип недопустимости презумпции отказа от права, по обоснованному заключению ученых [6, с. 79-98] и практики международных судебно-арбитражных органов [23, Р. 18], признан в качестве фундамента системы юридической безопасности (совокупность субъективных прав и законных интересов) государств. В параметрах проведения мероприятий по прохождению стадий договорного процесса заключения конвенционного акта заинтересованная сторона в лице субъекта внутригосударственного правопорядка (как часть суверенно целостного государства) призвана по логике вещей представить в обусловленные законодательством данного государства сроки свои собственные предложения в формате предмета совместного ведения. Фактическое отсутствие таковых в объективном порядке делает юридически обоснованным вывод об отказе обозначить свой правовой интерес в рамках заключения международного договора и тем самым предоставляет суверену правовой титул предпринять надлежащие юридические меры по завершению всего договорного процесса в режиме действующего и действительного международного договора. Таким образом, сам юридический факт непредставления соответствующих предложений в части обеспечения своих субъективных прав в должные, строго установленные, временные параметры с точки зрения общей юриспруденции не расценивается в качестве препятствия для заключения международного договора данного государства.

Российское государство в порядке подтверждения своей приверженности верховенству права выстраивает весь свой договорный процесс по заключению международных договоров с другими государствами - членами мирового сообщества в формате общепризнанных стандартов современной юриспруденции. Действующий в Российской Федерации Федеральный закон о международных договорах Российской 
Федерации от 15 июля 1995 г. № 101 - Ф3 (Принят Государственной Думой 16 июня 1995 г. ) представляет собой реальный юридический документ упорядоченного в рамках права процесса заключения международных договоров с участием Российского государства. Постановочное значение в плане решения всей проблемы заключения международных договоров Российской Федерации с предметной включенностью субъективных прав и законных интересов субъекта Российской Федерации имеют положения ст. 4 «Международные договоры Российской Федерации, затрагивающие полномочия субъекта Российской Федерации». Общая юридическая картина всех процедурных аспектов заключения международных договоров выстроена в формате строгой логики права. Предметно речь идет о следующем. Международный договор Российской Федерации, затрагивающй вопросы в формате ведения субъекта Российской Федерации, заключается по согласованию с органами государственной власти заинтересованного субъекта Российской Федерации, на которые возложена соответствующая функция. Соответственно, основополагающие положения или же сам проект подлежащего заключению международного договоpa, затрагивающего полномочия субъекта Российской Федерации по предметам совместного ведения Российской Федерации и субъектов Российской Федерации, направляются федеральными органами исполнительной власти органам государственной власти заинтересованного субъекта Российской Федерации, на которые возложена соответствующая функция. Поступившие предложения рассматриваются при подготовке проекта международного договора.

В порядке согласования вопросов заключения международного договора Российской Федерации органы государственной власти заинтересованного субъекта Российской
Федерации, на которые возложена соответствующая функция, уведомляются федеральными органами исполнительной власти о предельных сроках направления предложений, составляющих не менее двух недель. Непредставление в указанный срок ответа не препятствует внесению предложения о заключении международного договора Российской Федерации.

Весь круг вопросов относительно участия представителей органов государственной власти субъекта Российской Федерации в подготовке проекта международного договора, затрагивающего вопросы, относящиеся к ведению субъекта Российской Федерации, или его полномочия по предметам совместного ведения Российской Федерации и субъектов Российской Федерации, а также в переговорах и процедуре его подписания решается федеральными органами исполнительной власти по согласованию с органами государственной власти заинтересованного субъекта Российской Федерации, на которые возложена соответствующая функция.

Предметно обозначенный институционно-правовой формат включенности Российской Федерации (как государства с единой системой власти, пространственным верховенством и независимостью вовне) и заинтересованного субъекта Российской Федерации по линии заключения международных договоров Российской Федерации, затрагивающих полномочия субъекта Российской Федерации, в общих параметрах Федерального закона от 15 июля 1995 г. № 101-Ф3 установлен в четких границах верховенства права (как общего режима государственного обустройства Российской Федерации) и собственно правового поля Российского государства (по линии взаимодействия Российской Федерации как целостного, единого государства с субъектным составом Российской Федерации). 
Концептуально и практически обозначена структурно упорядоченная на основе права система включенности Российской Федерации в его качестве единого государства и заинтересованного субъекта Российской Федерации в процесс заключения международных договоров, затрагивающих полномочия субъекта Российской Федерации по предметам совместного ведения Российской Федерации и субъектов Российской Федерации. Весь комплекс мероприятий в формате выполнения предписаний законодательства Российской Федерации по линии заключения международных договоров Российской Федерации, затрагивающих полномочия субъекта Российской Федерации, осуществляется в режиме реального правового пространства государственного строительства России как правового государства Rule of Law State. Соответственно, каждый заинтересованный субъект Российской Федерации в рамках договорного процесса по выработке текста международного договора, затрагивающего полномочия субъекта Российской Федерации по предметам совместного ведения Российской Федерации и субъектов Российской Федерации, может и, по простой юридической логике, призван представить соответствующие предложения во временной формат «не менее двух недель» с целью предметного учета своего юридически обозначенного интереса (коль скоро в самом законодательном акте - Федеральном законе Российской Федерации от 15 июля 1995 г. речь идет об обеспечении субъективных прав «заинтересованного субъекта Российской Федерации»). Постановочно, юридический интерес «заинтересованного субъекта Российской Федерации» в общих параметрах науки и практики международной юриспруденции понимается как свободное волеизъявление субъекта права (в данном случае это право Российского государства в формате его внутреннего правопорядка) направить свои собственные предложения по линии подлежащего заключению международного договора в срок не менее двух недель. По обстоятельствам, когда затрагиваются полномочия субъекта Российской Федерации по предметам совместного ведения Российской Федерации и субъекта Российской Федерации, возможность направить свои собственные предложения по линии подлежащего заключению международного договора в срок не менее двух недель выступает и рассматривается с точки зрения современного международного права как право конкретного субъекта Российской Федерации. В ситуации осуществления процедуры по направлению своих собственных предложений по линии подлежащего заключению международного договора заинтересованный субъект Российской Федерации тем самым использует свое субъективное право в части учета его юридического интереса в общем тексте международного договора, заключаемого Российской Федерацией. И, наоборот, в ситуации не осуществления процедуры по направлению своих собственных предложений по линии подлежащего заключению международного договора в срок не менее двух недель общим юридическим правилом здесь является констатация конвенционного акта отказа от субъективного права. Юридическая сущность обозначенного здесь субъективного права проявляет себя в должном учете в тексте подлежащего заключению международного договора предложений со стороны субъекта Российской Федерации в части согласования вопросов заключения международного договора Российской Федерации. Процесс согласования, предметно указанный здесь, идет по двум позициям. Первое. В ситуации, когда затрагиваются вопросы, относящиеся к ведению субъекта Российской Федерации. 
Второе. При обстоятельствах, когда затрагиваются полномочия субъекта Российской Федерации по предметам совместного ведения Российской Федерации и субъектов Российской Федерации.

Концептуально и с точки зрения практики современного международного права, непредставление согласно ст. 4 Федерального закона от 15 июля 1995 г. предложений со стороны субъекта Российской Федерации по линии согласования вопросов заключения международного договора Российской Федерации в предельные сроки не менее двух недель имеет в качестве своего юридического свойства два последствия. Во-первых, сам факт непредставления не образует собой препятствие по пути внесения предложений о заключении международного договора Российской Федерации. Во-вторых, при обстоятельствах, когда факт непредставления образует собой отказ от субъективного права впоследствии (по прошествии не менее двух недель) направить предложения по линии согласования вопросов заключения международного договора Российской Федерации, сам факт непредставления не презимируется. В своем качестве общего принципа права (ст. 38 Статута Международного суда) принцип недопустимости презумпции отказа от права в предметных параметрах осуществления процедуры заключения международного договора, затрагивающего полномочия субъекта Российской Федерации по предметам совместного ведения Российской Федерации и субъектов Российской Федерации, параллельно с предоставлением права устанавливает предписание направить свои собственные предложения в предельные сроки не менее двух недель с целью согласования вопросов заключения международного договора, затрагивающего полномочия субъекта Российской Федерации по предметам совместного ведения Российской Федерации и субъектов Российской Федерации. Установленное здесь предписание носит характер предоставленного субъективного права, которое рассматривается как утратившее свою юридическую силу по обстоятельствам непредставления соответствующего предписания в срок не менее двух недель. Параметры верховенства права в параметрах предоставленного субъективного права здесь полностью соблюдены. Приоритет права над всеми другими соображениями здесь зафиксирован и подтвержден. Позиционно, внутригосударственное законодательство Российской Федерации в части правового регулирования процесса заключения международного договора, затрагивающего полномочия субъекта Российской Федерации по предметам совместного ведения Российской Федерации и субъектов Российской Федерации, всецело вписывается в параметры правового Российского государства. Действующая Конституция Российской Федерации 1993 г. в ст. 72 устанавливает целостный (в параметрах списочного состава) формат полномочий по предметам совместного ведения Российской Федерации и субъектов Российской Федерации. Ситуационно, юридический формат совместного ведения Российской Федерации и субъектов Российской Федерации обозначен и логически определяется в параметрах взаимодействия государственного суверена - Российской Федерации и производного от него (государственного суверена) субъекта права в лице субъекта Российской Федерации. Соответственно, и полномочия в параметрах полномочий по предметам совместного ведения Российской Федерации и субъектов Российской Федерации обозначаются в формате суверенного субъекта к производному субъекту. При этом весь позитив права в аспекте взаимодействия суверенного субъекта и производного субъекта обеспечивается в режиме целостной судебной системы 
Российской Федерации. Конституционный суд Российской Федерации как конкретный представитель этой целостной судебной системы Российской Федерации в своем определении от 6 декабря 2011 г. № 250-0 «По запросу Государственного Собрания - Курултая Республики Башкортостан о толковании ряда положений статей 5,11,71,72,73,76,77 и 78 Конституции Российской Федерации представил в параметрах юридически обоснованного документа правовой формат позиционирования Российской Федерации в ее качестве суверенного государства-члена мирового сообщества государств и субъекта Российской Федерации как составной части Российского государства. Первое. Установочное положение определения предписывает, что «Суверенитет Российской Федерации, в силу Конституции Российской Федерации... не допускает суверенитета ни республик, ни иных субъектов Российской Федерации». Суверенитет, как справедливо констатируется в определении, изначально принадлежит Российской Федерации в целом. Второе. Конституцией суверенитета Российской Федерации в режиме единой системы государственной власти, верховенством на всем пространственном протяжении государства и независимостью вовне никак «не затрагивается принадлежность республике всей полноты государственной власти, которой она..обладает вне пределов ведения Российской Федерации и полномочий Российской Федерации по предметам совместного ведения Российской Федерации и ее субъектов; равным образом не затрагивается и высшая юридическая сила конституции республики по вопросам, которые...относятся к ее ведению как субъекта Российской Федерации». Третье. «Принадлежащая субъекту Российской Федерации полнота государственной власти..., приоритет нормативного правового акта субъекта Российской Федерации..., самостоятельное установление субъектом Российской Федерации своей системы органов государственной власти...не могут рассматриваться республикой в качестве ее суверенных прав и суверенных полномочий со всеми вытекающими последствиями». В системе конституционно-правового взаимодействия между государственным сувереном и уполномоченным субъектом данного суверена издаваемые ими юридические акты в силу логике вещей соотносятся как основное и производное. Четвертое. В режиме «государственной целостности и единства системы государственной власти..., верховенства Конституции Российской Федерации и федеральных законов, которые имеют прямое действие и применяются на все территории Российской Федерации, включающей в себя территории ее субъектов...только Российская Федерация вправе заключать международные договоры, приоритет которых признается в ее правовой системе, и только Российская Федерация как суверенное государство может передавать межгосударственным объединениям свои полномочия в соответствии с международным договором». При обстоятельствах, когда договаривающейся стороной международного конвенционного акта является суверенное государство, только Российская Федерация в качестве ее суверенного государства, Великой державы, постоянного члена Совета Безопасности ООН вправе осуществлять процедуру по заключению международных договоров. Пятое, последнее, положение Определения Конституционного суда Российской Федерации несет в себе нормоустанавливающее, главенствую щее значение: «Приоритет положений Конституции Российской Федерации имеет место при определении как статуса субъекта Российской Федерации, так и предметов ведения и полномочий органов государственной власти Российской Федерации и 
органов государственной власти ее субъектов». Концептуальный позитив Определения Конституционного суда от 6 декабря 2001 г. в формате международно-правовой включенности Российской Федерации в договорную систему устанавливает предельно четкую юридическую конструкцию: в ситуации, когда субъекты Российской Федерации не имеют статуса суверенного государства, полномочной стороной международных договорно-правовых актов всегда и везде выступает Российская Федерация в ее признанном юридическом качестве государственного суверена, независимого участника международной договорной системы.

Представленный здесь концептуальный вывод предметно вписывается в постановления Федерального закона Российской Федерации от 15 июля 1995 г. № 101-Ф3, а именно: «В соответствии с Конституцией Российской Федерации заключение, прекращение и приостановление действия международных договоров Российской Федерации находится в ведении Российской Федерации» (ст. 3). При обстоятельствах установочного подтверждения исключительного права России как суверенного государства на заключение, прекращение, приостановление действия международных договоров Российской Федерации общий реестр международных договоров Российской Федерации покрывает собой межгосударственные договоры (международные договоры Российской Федерации заключаются с иностранными государствами, а также с международными организациями и иными образованиями от имени Российской Федерации); межправительственные договоры (от имени Правительства Российской Федерации); договоры межведомственного характера (от имени федеральных органов исполнительной власти или уполномоченных организаций). Будучи все международными договорами Российской Федерации, межгосударственные, межправительственные и договора межведомственного характера заключаются от имени Российской Федерации как государства в его качестве носителя государственного суверенитета.

Включенность Российского государства как суверена в систему международных правоотношений предопределено статусом и ролью Президента России как главы государства и гаранта Конституции Российской Федерации (ст. 80 Конституции РФ). В своем качестве главы государства и гаранта Конституции Российской Федерации Президент России выступает как глава Российского государства в его целостности и в режиме единой системы государственной власти. В общих параметрах конституционно-правового пространства Российского государства Президент России как глава государства: 1) является гарантом Конституции РФ, прав и свобод человека и гражданина; 2) принимает надлежащие меры по охране суверенитета Российской Федерации; 3) обеспечивает согласованное действие всех органов государственной власти Российской Федерации; 4) определяет основные, основополагающие направления внутренней и внешней политики Российского государства; представляет Российскую Федерацию в ее целостности и в режиме единой системы государственной власти внутри Российской Федерации и в формате современных международных отношений [10, с. 393-419].

Позиционирование Президента России в качестве главы Российского государства в его целостности и в режиме единой системы государственной власти на всем пространстве страны предметно определяет роль Президента Российской Федерации в области обороны. В соответствии со ст. 4 Федерального закона от 31 мая 1996 г. № 61-Ф3 «Об обороне» Президент России как Верховный Главнокомандующий Вооруженными 
Силами Российской Федерации определяет основные направления военной политики Российской Федерации; утверждает военную доктрину Российской Федерации, План обороны Российской Федерации, Положение о военном планировании в Российской Федерации; осуществляет руководство Вооруженными Силами Российской Федерации, другими войсками, воинскими формированиями и органами; в случае агрессии или непосредственной угрозы агрессии против Российской Федерации, возникновение вооруженных конфликтов, направленных против Российской Федерации, объявляет общую или частичную мобилизацию, вводит на территории Российской Федерации или в отдельных ее местностях военное положение с незамедлительным сообщением об этом Совету Федерации и Государственной Думе, отдает приказ Верховного Главнокомандующего Вооруженными Силами Российской Федерации о ведении военных действий; исполняет полномочия в области обеспечения режима военного положения в соответствии с Конституцией Российской Федерации и федеральным конституционным законом. Общий формат полномочий Президента Российской Федерации в области обороны предопределен статусом Верховного Главнокомандующего Вооруженными Силами Российской Федерации.

Конституционно-правовой режим позиционирования Президента России как главы Российского государства в его целостности и в режиме единой системы государственной власти на всем пространственном протяжении страны предметно себя проявляет в формате включенности России (как Великой державы, постоянного члена Совета Безопасности ООН) в мероприятиях по поддержанию или восстановлению мира. Процедура в институционном плане всецело упорядочена в рамках Федерального зако- на от 26 июня 1995 г. № 93-Ф3 «О порядке предоставления Российской Федерацией военного и гражданского персонала для участия в деятельности по поддержанию или восстановлению международного мира и безопасности». В параметрах главы II «Порядок принятия решений о предоставлении Российской Федерацией военного и гражданского персонала для участия в миротворческой деятельности» (ст. 6-9) установлено: «Решение о направлении за пределы территории Российской Федерации отдельных военнослужащих для участия в миротворческой деятельности принимается Президентом Российской Федерации. Президент Российской Федерации определяет район действий указанных военнослужащих, их задачи, подчиненность, срок пребывания и порядок замены, а также устанавливает в соответствии с федеральными законами дополнительные гарантии и компенсации указанных военнослужащих и членам их семей. Президент Российской Федерации принимает решение об отзыве указанных военнослужащих, если в связи с изменением международной военно-политической обстановки дальнейшее их участие в миротворческой деятельности становится нецелесообразным» (ст. 6). В порядке выполнения предписаний Главы III «Порядок принятия решений о предоставлении Российской Федерацией воинских формирований Вооруженных Сил Российской Федерации для участия в международных принудительных действиях с использованием вооруженных сил» (ст. 10-12). Решение о направлении за пределы территории Российской Федерации воинских формирований Вооруженных Сил Российской Федерации для участия согласно Уставу ООН в международных принудительных действиях с использованием вооруженных сил принимается Президентом Российской Федерации на основании Постановления 
Совета Федерации о возможности использования Вооруженных Сил Российской Федерации за пределами территории Российской Федерации и в соответствии с ратифицированным и вступившем в силу для Российской Федерации международным договором либо, если заключение международного договора предполагается, в соответствии с федеральным законом» (ст. 10).

Институционно-правовой формат включенности Президента России в конституционно-правовое пространство Российской Федерации в качестве главы Российского государства в его целостности и в режиме единой системы государственной власти на всем пространственном протяжении страны подтверждает положение, согласно которому Конституция РФ связывает суверенитет Российской Федерации, ее конституционно-правовой статус и полномочия, а также конституционно-правовой статус субъектов Российской Федерации, не с их волеизъявлением в порядке договора, а волеизьявлением многонационального российского народа - носителя и единственного источника власти в Российской Федерации, который реализуя принцип равноправия и самоопределения народов, конституировал суверенную государственность России как исторически сложившиеся государственное единство в ее настоящем федеративном устройстве. Соответственно, субъекты Российской Федерации не обладают суверенитетом, который изначально принадлежит Российской Федерации в целом (п. 3. 1 Определения Конституционного Суда Российской Федерации от 6 декабря 2001 г. № 250-0).

В ситуации, когда суверенитет Российской Федерации как изначально принадлежащий Российской Федерации в целом не допускает суверенитета субъектов Российской Федерации, международная правосубъектность - в формате между- народной правоспособности (обладание субъективными правами) и международной дееспособности (обладание способностью к обеспечению субъективных прав) - представляет собой правовой титул исключительно и только Российского государства. У субъектов Российской Федерации отсутствуют признаки правоспособности субъектов международного права сформулированные К. А. Бекяшевым: а) известная внешняя обособленность; б) персонофикация; в) способность вырабатывать, выражать и осуществлять автономную волю; г) участвовать в принятии норм международного права $[15$, с. 146]. Отсутствие признаков еще раз подтверждает постулат о том, что субъекты Российской Федерации не могут в априори обладать международной правосубъектностью. Только Российское государство при обстоятельствах подтверждения своей международной правосубъектности может осуществлять действия по обеспечению своих субъективных прав в Международном суде. А ведь в этом и состоит юридическое существо понятия международной право- и дееспособности. В ст. 34 Статута Международного суда на это показательно сказано: «Только государства могут быть сторонами по делам, разбираемым Судом». При обстоятельствах, когда субъекты Российской Федерации не являются государствами, они не могут (согласно Статуту Международного суда) обращаться в суд и, соответственно, не обладая международной правосубъектностью, не могут осуществлять предусмотренную на этот счет международную право- и дееспособность.

По факту сделанного концептуального заключения доктринальные мнения ряд ученых-юристов о появлении у субъектов федерации международной правосубъектности $[17,11,1,16,19]$, представляются по своей юридической сути несостоятельными. 
Постановочно, признание суверенитета «верховенство государства на своей территории и независимость в международных отношениях» [19] как имманентно присущего юридического существа Российского государства в качестве субъекта международного права предопределяет весь вопрос о координации международной деятельности субъектов Российской Федерации в формате упорядоченности в комплексе следующих нормативно-правовых актов: Конституция РФ (ст. 72), Федеральный закон «О координации международных и внешнеэкономических связей субъектов Российской Федерации» от 4 января 1999 г. № 4-Ф3, Федеральный закон «О международных договорах Российской Федерации» от 15 июля 1995 г. № 101-Ф3, Федеральный закон «Об основах государственного регулирования внешнеторговой деятельности» от 8 декабря 2003 г. № 164-Ф3, Указ Президента РФ «О координирующей роли Министерства иностранных дел Российской Федерации в проведении единой внешнеполитической линии Российской Федерации» от 8 ноября 2011 г. № 1478, Указ Президента Российской Федерации «Вопросы Министерства иностранных дел Российской Федерации» от 11 июля 2014 г. № 865.

Позитив правоприменительной практики Российского государства по линии включенности в качестве суверенного субъекта международного права в современный миропорядок предметно обозначен заявленной приверженностью верховенству права.

Своей практической деятельностью по линии поддержания международной законности и правопорядка Российская Федерация в порядке обеспечения правосудия и верховенства права в международных делах содействует в полном соответствии с предписаниями Декларации тысячелетия 2000 г. и Итогового документа Всемирного саммита 2005 г. укреплению Международного суда как главного судебного орана Организации Объединенных Наций (п. 8 Декларации тысячелетия 2000 г. ; п. 134 Итогового документа Всемирного саммита 2005 г.). Позиционирование Международного суда во взаимосвязи с режимом верховенства права определяется той ролью, которую играет главный судебный орган ООН в обеспечении режима верховенства права. Посредством процедуры разрешения международных споров, переданных ему государствами (как единственно возможных сторон дел, разбираемых судом), Международный суд не просто разрешает дело по существу и выносит юридически обязательное для сторон решение, но и тем самым логическим образом содействует поддержанию режима верховенства права в системе международных отношений.

Российская Федерация как суверенный субъект международного права в формате государства-члена мирового сообщества качественно позитивно относится к деятельности Международного суда как органа по обеспечению верховенства права. Осознание Российской Федерацией значимости роли Международного суда в международной нормативной системе определяется той ролью, которую несет в себе суд в плане прогрессивного развития современного международного права и его институтов. Россия именно как государство с присущим ему суверенитетом, единой системой государственной власти, верховенством на всем пространственном протяжении Российского государства, независимостью во внешних делах показательно значимо вносит свой собственный, позиционный вклад в дело упрочнения международного правопорядка.

Позиционно, международно-правовая значимость вклада Российской Федерации в дело поддержания современного правопорядка проявляет себя в параметрах обеспечения выполняемости всего корпуса 
международных обязательств на основе принципа добросовестности, укрепления Международного Суда, как главного судебного органа ООН, обеспечение целостности универсальной системы международной безопасности, поддержание международной законности. Правопорядок по факту юридической включенности России в международную нормативную систему обретает реальные показатели поступательного продвижения мирового сообщества в направлении построения миропорядка на основе верховенства права в его сущностном восприятии.

\section{Библиография:}

1. Бузуртанова, Ф. А. Правовые аспекты международных договоров субъектов Российской Федерации с иностранными государствами: Дис...канд. юрид. наук. - 12. 00. 10 - Москва, 2000;

2. Дмитриева Г. К. Становление принципа недопустимости злоупотребления правом/Советский ежегодник международного права. 1987. М. 1988. с. 114,117;

3. Дмитриева Г. К. Принцип добросовестности в современном международном праве/Правоведение. 1979. N. 6. с. $85-86$;

4. Иванов С. Верховенство право в международных отношениях/Международная жизнь,2000. № 12. с. 62-67;

5. Каламкарян Р. А. Господство права Rule of Law в международных отношениях. М. , 2004;

6. Каламкарян Р. А. Международно-правовое значение односторонних юридических актов государств. М., 1984. С. 79-98

7. Каламкарян Р. А. Фактор времени в праве международных договоров. М., 1989. С. 9-76;

8. Каламкарян Р. А. , Мигачёв Ю. И. Международное право. М. ,1977. Книга первая. с. 104-129;

9. Ковалев А. А. Международное экономическое право и правовое регулирование международной экономической деятельностью. М. , 2007, с. 52-102;

10. Конституционное право России: Учебник для студентов вузов / А. С. Прудников и др. под ред. Б. С. Эбзеева, А. С. Прудникова, В. И. Авсеенко. - 4-е изд. , перераб. и доп. М. , 2010. С. 393-419

11. Кулагина, И. А. . Правосубъектность Российской Федерации в контексте международного права: Дис...канд. юрид. наук. - 12. 00. 10 - Москва, 2007;

12. Марочкин С. Ю. Верховенство права на внутригосударственном и международном уровнях/ Гос. и право. 2013. №10. С. 86;

13. Международное право/под общ. ред. А. Я. Капустина. М,2008. с. 106-130;

14. Международное право: учебник/ отв. Ред. А. Н. Вылежганин. М. , 2009. с. 124-140;

15. Международное публичное право: учеб. / Л. П. Анофриева, Д. К. Бекяшев, К. А. Бекяшев, В. В. Устинов; отв. Ред. К. А. Бекяшев - 3-е изд. прераб. И доп. - М. , 2004. С. 146.

16. Миронов В. П. Конституционно-правовые проблемы разграничения предметов ведения и полномочий в условиях российского федерализма: Дис. . . канд. юрид. наук. - 12. 00. 02-Екатеринбург, 2004.

17. Надирадзе, Н. А. Федеративное устройство государств: Международная правосубъектность субъектов федерации: Дис...канд. юрид. наук. - 12. 00. 10 - Москва, 2000;

18. Ударцев C. В. , Темербеков Ж. Р. Концепция "Rule of Law," (“Верховенство права") и "Rechtsstaat" (“Правовое государство"): сравнительный анализ// Гос. и право. 2015 №5. C. 5-17;

19. Ушаков Н. А. Суверенитет и его и во внутригосударственном и международном праве // Московский журнал международного права. 1994 . № 2, С. 5.

20. Черниченко С. . В. Контуры международного права. М. ,2014;

21. Шумилов В. М. Международное право. М. , 2012. С. 65-66;

22. C. I. J. Reports. 1995 P. 19-20; C. I. J. Reports. 1951. P. 116, 138-139

23. C. P. J. I. 1936. Serie A. № 10. P. 18

24. Deicey A. V. Introduction to the Study of the Law of Constitution. London,1960. 
25. Disey A. V. The introduction to the Study of the Law of Constitution. London,1956;

26. I. C. J. Reports, 1949. P. 178-179

27. I. C. J. Reports. 1974. P. 269.

28. I. C. J. Yearbook 2003-2004. N. Y. , 2004. P. 115

29. Jackson S. W. Rule of Law among nations//The rule of Law. Dallas, 1965. p. 81;

30. Jacque J. P. Éléments pour une théorie de l'acte juridique en droit international public, Paris, 1972, P 171

31. Judicial Settlement of International Disputes/ International Disputes/ International Court of Justice. Other Courts and Tribunals. Arbitration and Conciliation/ Berlin, Heidelberg, New York, 1974. P. 3-19

32. Mash N. The role of Law: A Supra national concept//Oxford essays in jhurisprudence. London, 1960. p. 223;

33. P. C. I. J. 1923. Ser. A. N. 1. P. 28

34. P. C. I. J. Ser. A/B. №53. p. 45-46;

35. Paul V. The Abuse of rights and bona fides in international law / Österreichische Zeitschrift für offentliches Recht und Völkerrecht. 1977. Bd. 1/2. S. 125,127,128-129;

36. Rule of Law/Ed. H. M. Mackdonald, T. F. Cohen, A. L. Haerding, S. W. Jackson, with introd. вy A. L. Harding. Dallas, 1961. p. 3-71

37. Schwarzenberger G. The dynamics of international law. London,1976. P. 8,56;

38. SchwarzenbergerG. International Law. London,1976. Vol. 3. P. 450;

39. Seymour N. , Sherman W. The evolving concept of the rule of law//Journal ICJ. 1963. N4. p. 269;

40. Zoller E. La bonne foi en droit international public. Paris, 1977. P. 350

\section{References (transliterated):}

1. Buzurtanova, F. A. Pravovye aspekty mezhdunarodnykh dogovorov sub"'ektov Rossiiskoi Federatsii s inostrannymi gosudarstvami: Dis...kand. yurid. nauk. - 12.00. 10 - Moskva, 2000;

2. Dmitrieva G. K. Stanovlenie printsipa nedopustimosti zloupotrebleniya pravom/Sovetskii ezhegodnik mezhdunarodnogo prava. 1987. M. 1988. s. 114,117;

3. Dmitrieva G. K. Printsip dobrosovestnosti v sovremennom mezhdunarodnom prave/Pravovedenie. 1979. N. 6. s. 85-86;

4. Ivanov S. Verkhovenstvo pravo v mezhdunarodnykh otnosheniyakh/Mezhdunarodnaya zhizn',2000. № 12. s. 62-67;

5. Kalamkaryan R. A. Gospodstvo prava Rule of Law v mezhdunarodnykh otnosheniyakh. M. , 2004;

6. Kalamkaryan R. A. Mezhdunarodno-pravovoe znachenie odnostoronnikh yuridicheskikh aktov gosudarstv. M. , 1984. S. 79-98

7. Kalamkaryan R. A. Faktor vremeni v prave mezhdunarodnykh dogovorov. M., 1989. S. 9-76;

8. Kalamkaryan R. A., Migachev Yu. I. Mezhdunarodnoe pravo. M. ,1977. Kniga pervaya. s. 104-129;

9. Kovalev A. A. Mezhdunarodnoe ekonomicheskoe pravo i pravovoe regulirovanie mezhdunarodnoi ekonomicheskoi deyatel'nost'yu. M. , 2007, s. 52-102;

10. Konstitutsionnoe pravo Rossii: Uchebnik dlya studentov vuzov / A. S. Prudnikov i dr. pod red. B. S. Ebzeeva, A. S. Prudnikova, V. I. Avseenko. - 4-e izd., pererab. i dop. M. , 2010. S. 393-419

11. Kulagina, I. A. . Pravosub"ektnost' Rossiiskoi Federatsii v kontekste mezhdunarodnogo prava: Dis... kand. yurid. nauk. - 12.00. 10 - Moskva, 2007;

12. Marochkin S. Yu. Verkhovenstvo prava na vnutrigosudarstvennom i mezhdunarodnom urovnyakh/ Gos. i pravo. 2013. №10. S. 86;

13. Mezhdunarodnoe pravo/pod obshch. red. A. Ya. Kapustina. M,2008. s. 106-130;

14. Mezhdunarodnoe pravo: uchebnik/ otv. Red. A. N. Vylezhganin. M. , 2009. s. 124-140;

15. Mezhdunarodnoe publichnoe pravo: ucheb. / L. P. Anofrieva, D. K. Bekyashev, K. A. Bekyashev, V. V. Ustinov; otv. Red. K. A. Bekyashev-3-e izd. prerab. I dop. - M. , 2004. S. 146.

16. Mironov V. P. Konstitutsionno-pravovye problemy razgranicheniya predmetov vedeniya i polnomochii v usloviyakh rossiiskogo federalizma: Dis. . kand. yurid. nauk. - 12. 00. 02-Ekaterinburg, 2004. 
DOI: $10.7256 / 2226-6305.2016 .3 .17366$

При цитировании этой статьи сноска на doi обязательна

Международное право и международные организации•3•2016

International Law and International Organizations

17. Nadiradze, N. A. Federativnoe ustroistvo gosudarstv: Mezhdunarodnaya pravosub"'ektnost' sub"ektov federatsii: Dis...kand. yurid. nauk. - 12. 00. 10 - Moskva, 2000;

18. Udartsev S. V. , Temerbekov Zh. R. Kontseptsiya "Rule of Law," ("Verkhovenstvo prava") i "Rechtsstaat" ("Pravovoe gosudarstvo"): sravnitel’nyi analiz// Gos. i pravo. 2015 №5. S. 5-17;

19. Ushakov N. A. Suverenitet i ego i vo vnutrigosudarstvennom i mezhdunarodnom prave // Moskovskii zhurnal mezhdunarodnogo prava. 1994 . № 2, S. 5.

20. Chernichenko S. . V. Kontury mezhdunarodnogo prava. M. ,2014;

21. Shumilov V. M. Mezhdunarodnoe pravo. M. , 2012. S. 65-66;

22. Deicey A. V. Introduction to the Study of the Law of Constitution. London, 1960.

23. Disey A. V. The introduction to the Study of the Law of Constitution. London,1956;

24. Jackson S. W. Rule of Law among nations//The rule of Law. Dallas, 1965. p. 81;

25. Jacque J. P. Éléments pour une théorie de l'acte juridique en droit international public, Paris, 1972, P 171

26. Judicial Settlement of International Disputes/ International Disputes/ International Court of Justice. Other Courts and Tribunals. Arbitration and Conciliation/ Berlin, Heidelberg, New York, 1974. P. 3-19

27. Mash N. The role of Law: A Supra national concept//Oxford essays in jhurisprudence. London, 1960. p. 223;

28. Paul V. The Abuse of rights and bona fides in international law / Österreichische Zeitschrift für offentliches Recht und Völkerrecht. 1977. Bd. 1/2. S. 125,127,128-129;

29. Rule of Law/Ed. H. M. Mackdonald, T. F. Cohen, A. L. Haerding, S. W. Jackson, with introd. vy A. L. Harding. Dallas, 1961. p. 3-71

30. Schwarzenberger G. The dynamics of international law. London,1976. P. 8,56;

31. SchwarzenbergerG. International Law. London,1976. Vol. 3. P. 450;

32. Seymour N. , Sherman W. The evolving concept of the rule of law//Journal ICJ. 1963. N4. p. 269;

33. Zoller E. La bonne foi en droit international public. Paris, 1977. P. 350 